Original Research

\title{
Phenolic Wastewater Treatment via Catalytic Gasification
}

\author{
Shiyou Li, Qingpeng Wei, Shuibo Xie*, Taotao Zeng, Lishan Rong \\ Department of Municipal Engineering, School of Urban Construction, University of South China
}

Received: 28 September 2014

Accepted: 12 November 2014

\begin{abstract}
Phenolic wastewater comes mainly from coking, gas, and petrochemical plants, and other industrial sectors, as well as petroleum cracking ethylene, synthetic phenol, poly Thalidomide fibers, organic pesticides, and the phenolic resin production process. Phenolic compounds are monitoring our priority persistent organic compounds, having already been included in the column of carcinogenic single ring aromatics. In this paper, catalytic supercritical water gasification was applied to treat the phenolic wastewater. The influence of alkali on the gasification of phenolic wastewater with $\mathrm{NaOH}$ as catalyst at $580^{\circ} \mathrm{C}, 27 \mathrm{MPa}$ was investigated. The results showed that the $\mathrm{NaOH}$ addition increased $\mathrm{H}_{2}$ fraction and gas yield. The reaction mechanism was analyzed.
\end{abstract}

Keywords: phenolic wastewater, catalytic gasification, supercritical water, $\mathrm{NaOH}, \mathrm{H}_{2}$ fraction

\section{Introduction}

Phenolic wastewater originated from many sources covering chemical, oil shale retorting, and coking plants, in addition to oil refineries. Phenolic wastewater poses a major hazard, and contains a wide range of industrial pollutants such as phenols, cyanides, unsaturated hydrocarbons, and polycyclic and heterocyclic compounds, which can induce carcinogenesis, teratogenesis, and mutagenesis [1-6]. Furthermore, phenolic wastewater is on the priority list of 12 pollutants to be controlled by the U.S. Environmental Protection Agency [7, 8]. At present, domestic and foreign common methods for treating phenolic wastewater include mainly physical, chemical, and biochemical methods. But the treatment effects are not very satisfactory and are high in operating cost [9-17].

Supercritical water gasification (SCWG) is a promising technology since it can produce hydrogen by complete gasification of organic matters in water without a drying procedure, which is an energy-intensive process

*e-mail: xieshuibo1999@126.com and requires pretreatment of aqueous feedstock in conventional gasification processes. Furthermore, supercritical water has an extraordinary ability to suppress char formation during the decomposition of organic compounds [18-21]. Char is known to be a refractory byproduct formed in a significant amount during steam gasification of biomass at atmosphere [22], or hydrothermal treatments of glucose and cellulose [23] in hot liquid water at temperatures up to $350^{\circ} \mathrm{C}$ (sub-critical water conditions) unless appropriate catalysts are used. These impressive abilities of supercritical water to treat organic materials are based on its unique thermo physical properties [24]. Under SCWG conditions, water is not only a solvent, but also an active reactant contributing to gasification chemistry [25].

In this study, the influence of $\mathrm{NaOH}$ in $\mathrm{SCWG}$ of phenolic wastewater was studied. Firstly, the gasification performance of phenolic wastewater with and without $\mathrm{NaOH}$ in supercritical water was compared. Then the influence of the accumulative alkali in the reactor on the subsequent gasification of phenolic wastewater without alkali was studied with a longer residence time. 


\section{Experiments}

\section{Apparatus and Method}

The experiments were conducted in a laboratory-scale batch reactor with a volume of $650 \mathrm{~mL}$ designed to a maximum temperature and pressure of $600^{\circ} \mathrm{C}$ and $40 \mathrm{MPa}$. The flow diagram of the experimental setup is shown in Fig. 1. All wetted parts, from the pumps to the condenser, were made of stainless steel (1Cr18Ni9Ti). The stirrer was used to keep from the formation of char result from thermal cracking of phenolic wastewater at the walls of the reactor. The electric furnace was used as heater. The heating wires of the electric furnace were placed below and around the reactor. The reaction temperature was monitored directly using thermocouple (inserted inside the reactor) and controlled within $1^{\circ} \mathrm{C}$ by a temperature controller (Beijing Huaimi Instrumentation Co., N-9000 Digital Controller). Before the experiment, the reactor was loaded with phenolic wastewater and deionized water to bring the total volume of liquid to $100-140 \mathrm{~mL}$. Then, nitrogen gas was used to purge the reactor for $20 \mathrm{~min}$. After purging, the reactor was heated for about $60 \mathrm{~min}$. Upon reaching the reaction condition of reaction temperature $580^{\circ} \mathrm{C}$ and pressure 27 $\mathrm{MPa}$, reaction temperature remained stable within $1^{\circ} \mathrm{C}$, then the specified amount of $\mathrm{NaOH}$ was fed into the reactor at room temperature. The reaction was conducted for a given reaction time from 15 to $65 \mathrm{~min}$. After the reaction, the sample valve of the reactor was opened and the effluent was cooled rapidly in a shell and tube heat exchanger and then depressurized to ambient conditions. The product stream was then separated into liquid and vapor phases. The liquid products were collected in a graduated cylinder. Gaseous samples were collected with sample tubes.

\section{Chemical Analysis}

The gas yield was measured by a wet type flow meter. The composition of the gas product was analyzed by gas chromatography (Perkinelmer Clarus 680) with a thermal conductivity detector (TCD). The high-purity helium is used as carrier gas (purity $>99.999 \%$ ). A carbon molecular sieve column (TDX-01) purchased from Shanghai Datian Analytic Instrument Co., Ltd. in China is used, operating at $75^{\circ} \mathrm{C}$ for $3 \mathrm{~min}$, heating at $55^{\circ} \mathrm{C} / \mathrm{min}$ ramp to $145^{\circ} \mathrm{C}$, and holding for $15 \mathrm{~min}$. The determination of the sodium content in the aqueous sample was conducted in inductively coupled plasma-atomic emission spectrometry.

\section{Results and Discussion}

\section{SCWG of Phenolic Wastewater without $\mathrm{NaOh}$ Addition}

Phenolic wastewater was gasified without catalyst addition at $580^{\circ} \mathrm{C}$ and $27 \mathrm{MPa}$ in the batch reactor for a long reaction time. For comparison, the concentration of the

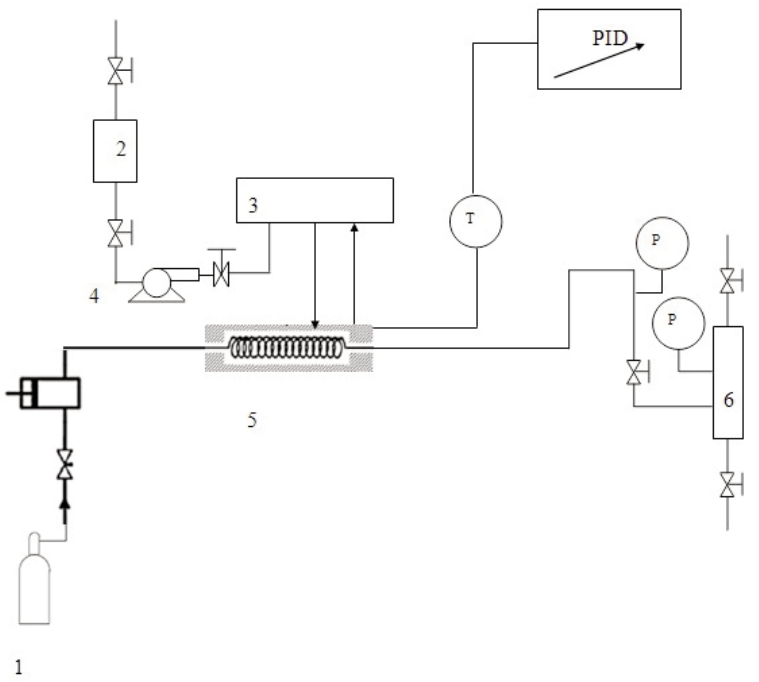

Fig. 1. Schematic diagram of the experimental setup. 1 - Nitrogen tank, 2 - Oxidant tank, 3 - Heater, 4 - High-pressure pump, 5 - Reactor, 6 - Gas-liquid separator

phenolic wastewater is kept at $6000 \mathrm{mg} / \mathrm{L}$ for all the experiments in this study. $\mathrm{H}_{2}, \mathrm{CH}_{4}, \mathrm{CO}$, and $\mathrm{CO}_{2}$ were main compositions of the gas product. The results changed with the reaction time changing (Fig. 2). It can be seen that $\mathrm{CO}$ fraction increased with the reaction time and the $\mathrm{H}_{2}$ fraction decreased. This may be because the reactant concentration in the reactor increased with more phenolic wastewater fed into the reactor in a longer reaction time. The previous literatures indicated that high concentration of biomass is hard to decompose and gasify [24]. More CO, lower gasification rate, and less $\mathrm{H}_{2}$ were generated in the process of SCWG of biomass with higher concentration, and they are consistent with the variation trend of gasification results at an earlier stage. Moreover, during the process of SCWG, reaction environment in the reactor are changed by phenolic wastewater decomposition. The generated intermediates from decomposition of phenolic wastewater may have negative effects on WGS reaction, which led to higher CO fraction and lower $\mathrm{H}_{2}$ fraction. After $20 \mathrm{~min}$ of reaction, the gas product reached a stable state and remained constant. The gas product under the stable state contained about $27 \% \mathrm{CO}$, $34 \% \mathrm{CO}_{2}, 9 \% \mathrm{CH}_{4}$, and $30 \% \mathrm{H}_{2}$, and the gas yield was 16 $\mathrm{mol} / \mathrm{kg}$.

\section{SCWG of Phenolic Wastewater with $25 \mathrm{mg} / \mathrm{L} \mathrm{NaOH}$}

When catalyst $(25 \mathrm{mg} / \mathrm{L} \mathrm{NaOH}$ ) was added to the reactor for SCWG of phenolic wastewater at $27 \mathrm{MPa}$ and $580^{\circ} \mathrm{C}$, the composition and yield of gas product was shown in Fig. 3. The variation was different from non-catalytic gasification. After reaction of $35 \mathrm{~min}$, the composition of gas was stable. The composition of gas product is mainly about $4 \% \mathrm{CO}, 42.5 \% \mathrm{CO}_{2}, 48 \% \mathrm{H}_{2}$, and $5.5 \% \mathrm{CH}_{4}$ under the stable state. Less $\mathrm{CO}$ and more $\mathrm{H}_{2}$ were generated comparing with the gas product obtained from non-catalytic gasification as described above. This difference was report- 


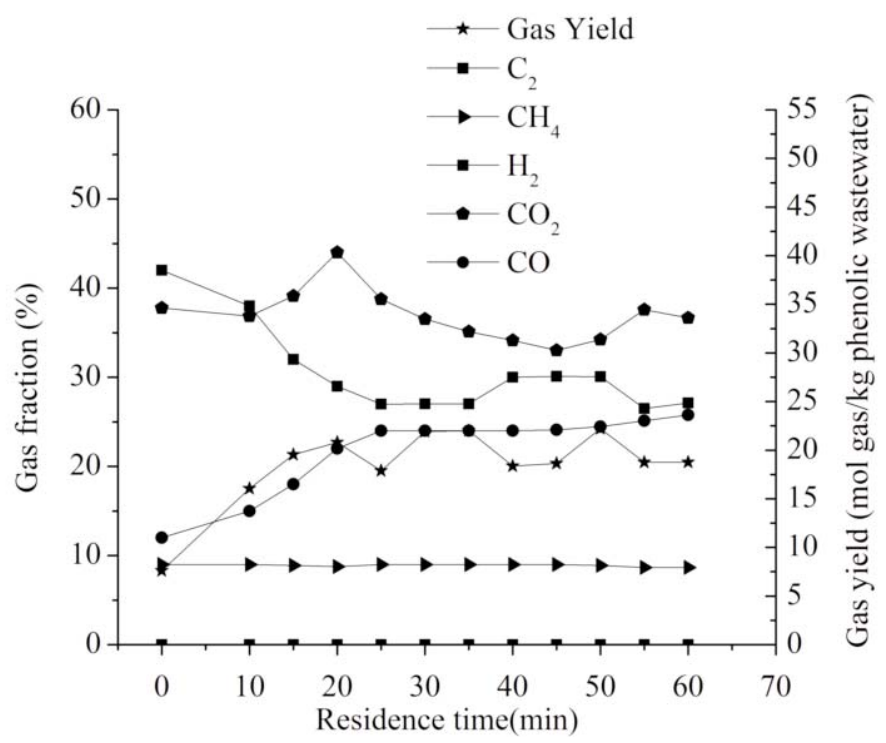

Fig. 2. The composition and total yield of the gas product from SCWG of phenolic wastewater $\left(580^{\circ} \mathrm{C}, 27 \mathrm{MPa}, 6000 \mathrm{mg} / \mathrm{L}\right)$.

ed in several literatures that are attributed to the acceleration of WGS reaction by alkali. In addition, the gas yield increased owning to the presence of $\mathrm{NaOH}$. The total gas yield reached about $21 \mathrm{~mol} / \mathrm{kg}$ when reaction time was 45 min, which was higher than noncatalytic gasification of phenolic wastewater (about $16 \mathrm{~mol} / \mathrm{kg}$ ).

For SCWG of phenolic wastewater without $\mathrm{NaOH}$ addition, another difference was that the gasification results with adding $25 \mathrm{mg} / \mathrm{L} \mathrm{NaOH}$ took a longer time to reach the stable state. The composition of gas took about $35 \mathrm{~min}$ to reach the stable state with adding $25 \mathrm{mg} / \mathrm{L} \mathrm{NaOH}$ as the catalyst. For the gas yield, longer time was taken (about 45 $\mathrm{min}$ ). Both of them were longer than SCWG of phenolic wastewater without catalyst addition (20 min, Fig. 2).

As described above, at the earlier stage the increasing concentration and the generated intermediates played a negative role in gasification, which increased the $\mathrm{CO}$ fraction and decreased total gas yield, the $\mathrm{H}_{2}$ fraction. However, variation tendency of the catalytic gasification results with $25 \mathrm{mg} / \mathrm{L} \mathrm{NaOH}$ was opposite to non-catalytic gasification of phenolic wastewater. At the earlier stage, CO fraction was continuously decreasing, while $\mathrm{H}_{2}$ fraction and gas yield were continuously increasing. The opposite variation tendency depended on the precipitation of alkalis in the reactor. As described above, because the inorganic matters kept low solubility in supercritical water and they can precipitate in the reactor. The precipitation of the alkali can lead to the accumulation of the alkali in the reactor within a longer reaction time. It is known that from Le Chatelier's principle, when concentration of alkali increased, the reaction equilibrium is shifted to the positive direction. That is conducive to WGS reaction. In addition, concentration of alkali increased and it led the percentage of activated molecular in unit volume increased. It is known that from collision theory, increasing the percentage of activated molecular in unit volume will lead to higher effective collision

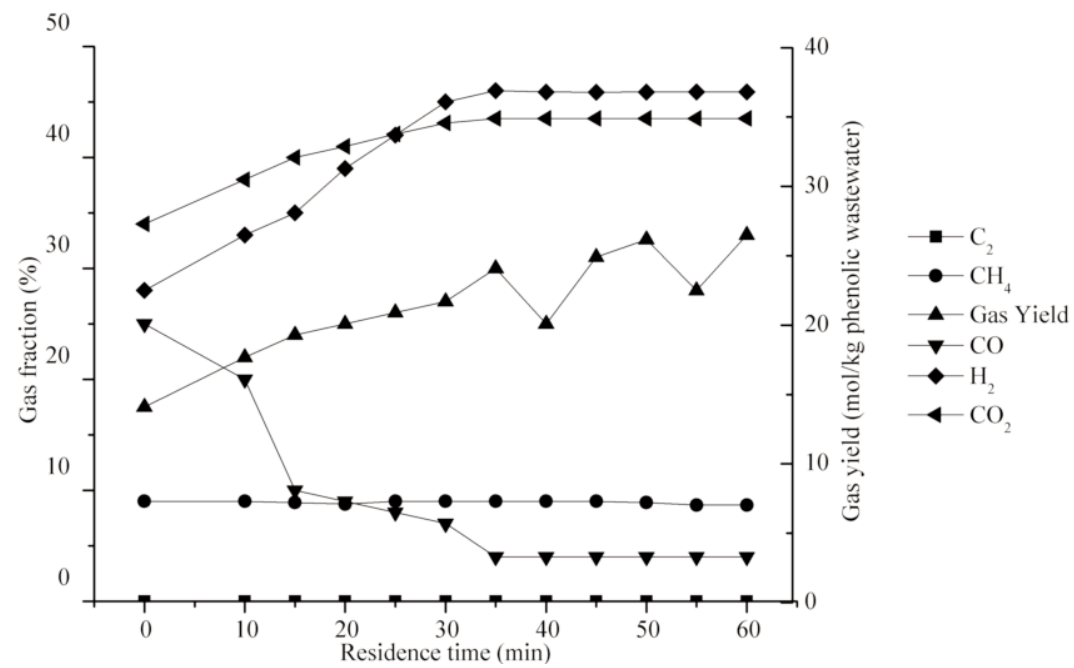

Fig. 3. The composition and total yield of the gas product from SCWG of phenolic wastewater with $25 \mathrm{mg} / \mathrm{L} \mathrm{NaOH}$ as the catalyst $\left(580^{\circ} \mathrm{C}, 27 \mathrm{MPa}, 6000 \mathrm{mg} / \mathrm{L}\right)$. 
and more reaction probability of particles. As a result, a different variation tendency was obtained from that without catalyst, where the $\mathrm{H}_{2}$ fraction and gas yield increased and the $\mathrm{CO}$ fraction decreased with the reaction time in the earlier stage. This may also be the reason for the longer unstable time in $\mathrm{NaOH}$-catalyzed SCWG of phenolic wastewater than non-catalytic gasification.

\section{SCWG of Phenolic Wastewater with $75 \mathrm{mg} / \mathrm{L} \mathrm{NaOH}$}

We also conducted phenolic wastewater treatment via SCWG with $75 \mathrm{mg} / \mathrm{L} \mathrm{NaOH}$ as the catalyst at $27 \mathrm{MPa}$ and $580^{\circ} \mathrm{C}$. The results also varied with the reaction time at the earlier stage because of $\mathrm{NaOH}$ (Fig. 4). The composition of gas and yield from this experiment took less time to reach the stable state compared with SCWG of phenolic wastewater with $25 \mathrm{mg} / \mathrm{L} \mathrm{NaOH}$. The composition of gas took about 20 min to reach the stable state (Fig. 4), and it is almost half that with $25 \mathrm{mg} / \mathrm{L} \mathrm{NaOH}$. As described above, concentration of alkali in the reactor and their catalytic effect can improve owning to the precipitation and accumulation of $\mathrm{Na}$ salts. This caused $\mathrm{H}_{2}$ fraction increase and $\mathrm{CO}$ fraction decrease. While enough alkali for SCWG of phenolic wastewater is accumulated in the reactor after a certain time, the results reached a stable state. The composition of gas from SCWG of phenolic wastewater with $75 \mathrm{mg} / \mathrm{L} \mathrm{NaOH}$ took less time to reach stable state. The reason may be that the concentration of $\mathrm{Na}^{+}$salts provided with $75 \mathrm{mg} / \mathrm{L} \mathrm{NaOH}$ in this experiment was more than that with $25 \mathrm{mg} / \mathrm{L} \mathrm{NaOH}$. Reaction speed for SCWG of phenolic wastewater with $75 \mathrm{mg} / \mathrm{L}$ $\mathrm{NaOH}$ is faster than that with $25 \mathrm{mg} / \mathrm{L} \mathrm{NaOH}$. Therefore, it reached the saturated state more quickly than that with 25 $\mathrm{mg} / \mathrm{L} \mathrm{NaOH}$.

It is also worth noting that similar gasification results were gained from phenolic wastewater with different con- centrations of $\mathrm{NaOH}$ at the stable state. After a reaction time of $20 \mathrm{~min}$, the composition of gas product from phenolic wastewater with $75 \mathrm{mg} / \mathrm{L} \mathrm{NaOH}$ reached stable state (Fig. 4). The composition of gas is mainly about $48 \% \mathrm{H}_{2}$, $43 \% \mathrm{CO}_{2}, 2 \% \mathrm{CO}$, and $4.5 \% \mathrm{CH}_{4}$. This was very similar to the gas product from phenolic wastewater with $25 \mathrm{mg} / \mathrm{L}$ $\mathrm{NaOH}$ in the stable state under the same reaction condition. The gas yield from SCWG of phenolic wastewater with 75 $\mathrm{mg} / \mathrm{L} \mathrm{NaOH}$ is about $21 \mathrm{~mol} / \mathrm{kg}$, which is also close to that with $25 \mathrm{mg} / \mathrm{L} \mathrm{NaOH}$ as the catalyst (about $20.9 \mathrm{~mol} / \mathrm{kg}$ ). These results may be related to the accumulation of alkali in the reactor.

\section{Reaction Pathway}

According to previous works, the main reactions in the gasification of organic compounds in SCW include steam reforming (Reaction (1)), water gas shift reaction (Reaction (2)) and methanation reaction (Reactions (3) and (4)) [26].

$$
\begin{array}{ll}
\mathrm{CH}_{\mathrm{n}} \mathrm{O}_{\mathrm{m}}+(1-\mathrm{m}) \mathrm{H}_{2} \mathrm{O} \rightarrow(\mathrm{n} / 2+1-\mathrm{m}) \mathrm{H}_{2}+\mathrm{CO} \\
\mathrm{CO}+\mathrm{H}_{2} \mathrm{O} \rightarrow \mathrm{CO}_{2}+\mathrm{H}_{2} & \Delta H_{298}^{0}=-41 \mathrm{~kJ} / \mathrm{mol} \\
\mathrm{CO}+3 \mathrm{H}_{2} \rightarrow \mathrm{CH}_{4}+\mathrm{H}_{2} \mathrm{O} & \Delta H_{298}^{0}=-211 \mathrm{~kJ} / \mathrm{mol} \\
\mathrm{CO}_{2}+4 \mathrm{H}_{2} \rightarrow \mathrm{CH}_{4}+2 \mathrm{H}_{2} \mathrm{O} & \Delta H_{298}^{0}=-223 \mathrm{~kJ} / \mathrm{mol}
\end{array}
$$

It is seen that the reforming reaction in the synthesis gas has two parallel reactions: $\mathrm{CH}_{4}$ is generated and $\mathrm{H}_{2}$ is consumed for 1:3 ratio during the methanation reaction (3), which is extremely detrimental for $\mathrm{H}_{2}$ conversion; the water gas shift reaction (4) is needed. Of course these two reactions cannot be very complete, so the final product will be a resulting gas steam reforming (2) of the product (referred to as synthesis gas). Obviously, to increase the conversion rate of $\mathrm{H}_{2}$ it is necessary to promote the water gas shift reaction (4), inhibiting the methanation reaction (3).

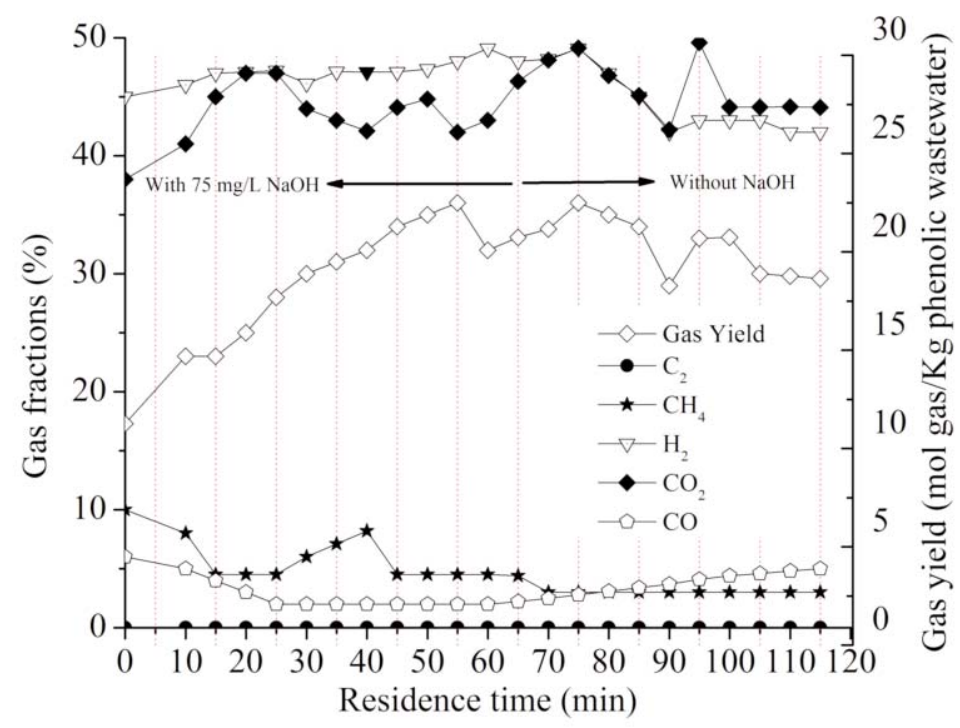

Fig. 4. The composition and total yield of the gas product from SCWG of phenolic wastewater with $75 \mathrm{mg} / \mathrm{L} \mathrm{NaOH}$ and without $\mathrm{NaOH}$ $\left(580^{\circ} \mathrm{C}, 27 \mathrm{MPa}, 6000 \mathrm{mg} / \mathrm{L}\right)$. 
In supercritical water, $\mathrm{NaOH}$ interact with phenolic wastewater and generated water-soluble products and oils, the former can be gasified to generate $\mathrm{H}_{2}, \mathrm{CO}, \mathrm{CO}_{2}$, and $\mathrm{CH}_{4}$, which promotes water-gas shift reaction in the positive direction, so as to promote $\mathrm{H}_{2}$.

$$
\begin{aligned}
& 2 \mathrm{NaOH}+\mathrm{CO}_{2} \rightarrow \mathrm{Na}_{2} \mathrm{CO}_{3}+\mathrm{H}_{2} \mathrm{O} \\
& \mathrm{Na}_{2} \mathrm{CO}_{3}+\mathrm{H}_{2} \mathrm{O} \rightarrow \mathrm{NaHCO}_{3}+\mathrm{NaOH} \\
& \mathrm{NaOH}+\mathrm{CO} \rightarrow \mathrm{HCOONa} \\
& \mathrm{HCOONa}+\mathrm{H}_{2} \mathrm{O} \rightarrow \mathrm{NaHCO}_{3}+\mathrm{H}_{2} \\
& 2 \mathrm{NaHCO}_{3} \rightarrow \mathrm{CO}_{2}+\mathrm{Na}_{2} \mathrm{CO}_{3}+\mathrm{H}_{2} \mathrm{O} \\
& \mathrm{H}_{2} \mathrm{O}+\mathrm{CO} \rightarrow \mathrm{H}_{2}+\mathrm{CO}_{2}
\end{aligned}
$$

\section{Conclusions}

In this paper, catalytic supercritical water gasification was applied to treat phenolic wastewater. The influence of alkali on the gasification of phenolic wastewater with $\mathrm{NaOH}$ as catalyst at $580^{\circ} \mathrm{C}, 27 \mathrm{MPa}$ was investigated. The results showed that the $\mathrm{NaOH}$ addition increased $\mathrm{H}_{2}$ fraction and gas yield. The gas product was mainly composed of $\mathrm{H}_{2}, \mathrm{CO}, \mathrm{CH}_{4}$, and $\mathrm{CO}_{2}$ in $\mathrm{SCWG}$ of phenolic wastewater at $27 \mathrm{MPa}$ and $580^{\circ} \mathrm{C}$. The presence of $\mathrm{NaOH}$ increased $\mathrm{H}_{2}$ fraction and decreased $\mathrm{CO}$ fraction in the gas product via promoting WGS reaction, and it also increased the gas yield. The precipitated alkali in the reactor still showed high catalytic effect on the subsequent gasification of phenolic wastewater without further addition of the alkali. The catalytic activity was slightly reduced, owning to the transformation of $\mathrm{NaOH}$ to $\mathrm{Na}_{2} \mathrm{CO}_{3}$ and $\mathrm{NaHCO}_{3}$.

\section{References}

1. MOUSSAVI G., BARIKBIN B., MAHMOUDI M. The removal of high concentrations of phenol from saline wastewater using aerobic granular SBR. Chem. Eng. J., 158, 498, 2010.

2. GUERRA R. Ecotoxicological and chemical evaluation of phenolic compounds in industrial effluents. Chemosphere, 44, 1737, 2001.

3. WANG H., GUAN Q.Q., LI J.X., WANG T.H. Phenolic wastewater treatment by an electrocatalytic membrane reactor. Catal. Today, 236, 121, 2014.

4. XU D.Y., YANG Z. Cross-linked tyrosinase aggregates for elimination of phenolic compounds from wastewater. Chemosphere, 92, 391, 2013.

5. FAN C.Z., LU A.H., LI Y., WANG C.Q. Pretreatment of actual high-strength phenolic wastewater by manganese oxide method. Chem. Eng. J., 160, 20, 2010.

6. ZHANG M.L., ZHI L., LI H.Z., LONG H.K., ZHAO W. Process integration of halogenation and oxidation for recovery and removal of phenols from high strength phenolic wastewater. Chem. Eng. J., 229, 99, 2013.

7. RAMAKRISHNAN A., GUPTA S.K. Effect of COD/NO$\mathrm{N}$ ratio on the performance of a hybrid UASB reactor treating phenolic wastewater. Desalination, 232, 128, 2008.

8. LU Y., YAN L.H., WANG Y., ZHOU S.F., FU J.J., ZHANG J.F. Biodegradation of phenolic compounds from coking wastewater by immobilized white rot fungus Phanerochaete chrysosporium. J. Hazard. Mater., 165, 1091, 2009.

9. PRATARN W., PORNSIRI T., THANIT S., TAWATCHAI C., WIWUT T. Adsorption and Ozonation Kinetic Model for Phenolic Wastewater Treatment. Chinese J. Chem. Eng., 19, 76, 2011.

10. HSIEN T.Y., LIN Y.H. Biodegradation of phenolic wastewater in a fixed biofilm reactor. Biochem. Eng. J., 27, 95, 2005.

11. MOHAMMADZADEH J.S.S., KHOSHFETRAT A.B., KAYNEJAD M.A. Pilot Scale System for Removal of Phenol in Phenolic Wastewater of Olefin Plant. Process Saf. Environ., 82, 365, 2004.

12. LIN S.H., WANG C.S. Treatment of high-strength phenolic wastewater by a new two-step method. J. Hazard. Mater., 90, 205, 2002.

13. CHENG J., YU S.M., ZUO P. Horseradish peroxidase immobilized on aluminum-pillared interlayered clay for the catalytic oxidation of phenolic wastewater. Water Res., 40, 283, 2006.

14. HUSSAIN A., KUMAR P., MEHROTRA I. Treatment of phenolic wastewater in UASB reactor: Effect of nitrogen and phosphorous. Bioresource Technol., 99, 8497, 2008.

15. HUSSAIN A., KUMAR P., MEHROTRA I. Nitrogen biotransformation in anaerobic treatment of phenolic wastewater. Desalination, 250, 35, 2010.

16. MARTINS R.C., ROSSI A.F., QUINTA-FERREIRA R.M. Fenton's oxidation process for phenolic wastewater remediation and biodegradability enhancement. J. Hazard. Mater., 180, 716, 2010.

17. DALAL S., GUPTA M.N. Treatment of phenolic wastewater by horseradish peroxidase immobilized by bioaffinity layering. Chemosphere, 67, 741, 2007.

18. LEE I.G. Effect of metal addition to Ni/activated charcoal catalyst on gasification of glucose in supercritical water. Int. J. Hydrogen Energ., 36, 8869, 2011.

19. DING N., AZARGOHAR R., DALAI A.K., KOZINSKI J.A. Catalytic gasification of glucose to $\mathrm{H}_{2}$ in supercritical water. Fuel Process. Technol., 127, 33, 2014.

20. REDDY S.N., NANDA S., DALAI A.K., KOZINSKI J.A. Supercritical water gasification of biomass for hydrogen production. Int. J. Hydrogen Energ, 39, 6912, 2014.

21. LU Y.J., ZHU Y.M., LI S., ZHANG X.M., GUO L.J. Behavior of nickel catalysts in supercritical water gasification of glucose: Influence of support. Biomass Bioenerg., 67, 125, 2014.

22. REDDY S.N., NANDA S., DALAI A.K., KOZINSKI J.A. Supercritical water gasification of biomass for hydrogen production. Int. J. Hydrogen Energ. 39, 6912, 2009.

23. FANG Z., MINOWA T., FANG C., SMITH JR R.L., INOMATA H., KOZINSKI J.A. Catalytic hydrothermal gasification of cellulose and glucose. Int. J. Hydrogen Energ, 33, 981, 2008.

24. JIN H., LV Y.J., GUO L.J., CAO C.Q., ZHANG X.M. Hydrogen production by partial oxidative gasification of biomass and its model compounds in supercritical water. Int. J. Hydrogen Energ, 35, 3001, 2010.

25. ANTAL JR M.J., ALLEN S.G., SCHULMAN D., XU X. Biomass gasification in supercritical water. Industrial and Engineering Chemistry Research. 39, 4040, 2000.

26. KRUSE A., HENNINGSEN T., SINAĞ A., PFEIFFER J. Biomass Gasification in Supercritical Water: Influence of the Dry Matter Content and the Formation of Phenols. Ind. Eng. Chem. Res., 42, 3711, 2003. 
